\title{
Isolation and molecular identification of antimicrobial-producing Lactic Acid Bacteria from chao, South Sulawesi (Indonesia) fermented fish product
}

\author{
RISKY NURHIKMAYANI ${ }^{1}$, BUDI SETIADI DARYONO ${ }^{2}$, ENDAH RETNANINGRUM ${ }^{1, \bullet}$ \\ ${ }^{1}$ Microbiology Laboratory, Faculty of Biology, Universitas Gadjah Mada. Jl. Teknika Selatan Sekip Utara, Sleman 55281, Yogyakarta, Indonesia. \\ Tel.: +62-274-580839, Fax.: +62-274-6492355,’email: endahr@ugm.ac.id \\ ${ }^{2}$ Genetic and Breeding Laboratory, Faculty of Biology, Universitas Gadjah Mada. Jl. Teknika Selatan Sekip Utara, Sleman 55281, Yogyakarta, Indonesia
}

Manuscript received: 23 May 2018. Revision accepted: 23 March 2019.

\begin{abstract}
Nurhikmayani R, Daryono BS, Retnaningrum E. 2019. Isolation and molecular identification of antimicrobial-producing Lactic Acid Bacteria from chao, South Sulawesi (Indonesia) fermented fish product. Biodiversitas 20: 1063-1068. Chao is traditional fermented fish made of anchovy (Stolephorus sp.), rice, salt, and fermented naturally on controlled environment. The product comes from Pangkep Regency, South Sulawesi. Chao has the potential for the source of high-grade lactic acid bacteria isolates, especially for antimicrobial compound. Antimicrobial compound produced by lactic acid bacteria is a biopreservative compound with many advantages. The purposes of this investigation were to isolate antimicrobial-producing lactic acid bacteria from chao and to identify their isolates based on the molecular properties. Lactic acid bacteria were isolated from chao using Man Ragosa Sharpe Agar (MRSA) medium added with $0.1 \% \mathrm{CaCO}_{3}$, followed by the ability test to produce antimicrobial compound against Staphylococcus aureus FNCC 0047 as an indicator. The spectrum of crude antimicrobial as cell-free supernatant (CFS) was determined by antagonism against $S$. aureus FNCC 0047 and Escherichia coli FNCC 0049 on agar well diffusion test. Selected isolates of antimicrobial-producing lactic acid bacteria molecularly identified from $16 \mathrm{~S}$ rRNA marker using primer 27F and 1492R. We obtained four isolates of lactic acid bacteria that showed the antimicrobial activity. This crude antimicrobial compound could inhibit both gram-positive Staphylococcus aureus FNCC0047 and gram-negative bacteria Escherichia coli FNCC0049. The highest crude antimicrobial activity of isolates was observed on IB1C strain. The results of molecular characterization suggested that the IB1C and IB3B strain were identified as Lactobacillus plantarum, whereas IB3E and IB3F were identified as Pediococcus pentosaceus.
\end{abstract}

Keywords: Antimicrobial, chao, lactic acid bacteria, Lactobacillus plantarum, Pediococcus pentosaceus

\section{INTRODUCTION}

Chao is a local fermented fish product of coastal communities from Pangkep Regency, South Sulawesi, Indonesia. It is produced by soaking the raw materials, including anchovy (Stolephorus sp.), rice and salt, then fermented naturally on controlled environment (Karim et al. 2013). The salt content of chao fermentation ranges from $15-20 \%$ that inhibit the growth of the non-tolerant microbes. Lactic acid bacteria are tolerant and adaptable to saline environment with concentrations of $10-18 \%$ (Sanches 2008; Agussalim 2017). This makes lactic acid bacteria becomes the dominant microorganism in chao fermentation products. Chao is also known to have a sour taste that indicates the main microorganism for fermentation activity is the lactic acid bacteria (LAB) group (Lakong 2003). The LAB was divided into 12 genera, i.e. Lactococcus, Leuconostoc, Pediococcus, Streptococcus, Lactobacillus, Enterococcus, Aerococcus, Vagococcus, Tetragenococcus, Carnobacterium, Weissella, and Oenococcus. These bacterial species in the LAB group are designated as LAB according to their ability to metabolize lactic acid (Ray 2005).

Lactic acid bacteria are gram-positive bacteria, endospores-negatives, catalase-negative, usually non- motile and producing antimicrobial components (Axelsson 2004). Antimicrobial substances of LAB such as lactic acid, hydrogen peroxide, diacetyl, and bacteriocin can inhibit pathogenic bacteria and spoilage bacteria. The ability of LAB to produce antimicrobial components can be used as a natural preservative (Adams and Moss 2008). The LAB are known as GRAS (Generally Regarded as Safe) because they are not toxic and do not produce a toxin, so they are not harmful to health, even these microorganism are useful for health (USFDA 2015). The use of LAB as a natural preservative agent can reduce the use of harmful synthetic preservatives. The ability of LAB as natural preservative has been widely reported, especially from fermented food. Indonesia has many fermented food but only few studies about Indonesian's fermented fish are available in literature such as jambal roti, peda (Indriati et al. 2006), bekasam (Desniar et al. 2015; Budiarto et al. 2016), and rusip (Koesoemawardani et al. 2018). As far as we know, there has been no research on antimicrobialproducing lactic acid bacteria from chao. This research aimed to isolate and identify antimicrobial-producing LAB from chao, South Sulawesi Fermented Fish Product. 


\section{MATERIALS AND METHODS}

\section{Indicator strains and growth conditions}

Staphylococcus aureus FNCC 0047 and Escherichia coli FNCC 0049 were obtained from the Food and Nutrition Culture Collection of Universitas Gadjah Mada. All strains were maintained in Nutrient Agar at $37^{\circ} \mathrm{C}$.

\section{Isolation of Lactic Acid Bacteria}

The sample of chao was obtained from the local market in Pangkep Regency, South Sulawesi, Indonesia. The sample was diluted 10 -fold in $0.85 \% \mathrm{NaCl}$ solution and mixed thoroughly. Then, $0.1 \mathrm{~mL}$ of each dilution was poured into MRS (Man Ragosa Sharpe) agar (Oxoid) with $0.1 \% \mathrm{CaCO}_{3}$ and incubated for $48 \mathrm{~h}$ at $37^{\circ} \mathrm{C}$ (AssohounDjeni et al. 2016; Sirichokchatchawan et al. 2018). Colonies producing clear halo were selected and restreaked on MRS agar plate to obtain pure cultures. Selected colonies were preliminary screened for lactic acid bacteria by Gram staining, catalase testing, endospore staining, and motility test. Colonies which were grampositive, catalase negative, endospore negative and nonmotile were subjected for further test.

\section{Detection of antimicrobial activity}

Antimicrobial activity was determined by well diffusion assay of LAB growing cells culture and cell-free supernatant (CFS) against indicator strain Staphylococcus aureus FNCC 0047. The antimicrobial activity of LAB growing cell was performed using the method described by Assohoun-Djeni et al. (2016) and Sirichokchatchawan et al. (2018). Overnight cultures of each LAB strains were placed in wells cut in Nutrient soft agar $(0.7 \%$ agar $)$ inoculated with $100 \mu \mathrm{L}$ of an overnight active culture of indicator bacteria. After incubation at $37^{\circ} \mathrm{C}$ for $24 \mathrm{~h}$, the plates were examined for the existent of clear halo around the well. The presence of distinguishable halo was considered as positive inhibition. Positive inhibition LAB strains were grown in MRS broth for overnight at $37^{\circ} \mathrm{C}$, then centrifuged $\left(12.000 \mathrm{rpm}\right.$ for $10 \mathrm{~min}$ at $4^{\circ} \mathrm{C}$, Sigma Santorius 3-30 K, England). Each supernatant was collected and filtered (0.2 $\mu$ pore sizes, Corning, Germany) to obtain CFS (Cell Free Supernatant). The CFS was placed in wells cut in nutrient soft agar seeded $(100 \mu \mathrm{L})$ with indicator strain. The antimicrobial spectrum of CFS was analysed by antagonism against Escherichia coli FNCC 0049 on agar well diffusion test. Each experiment was performed in triplicate. Antimicrobial activity was measured based on an inhibition score (IS). The inhibitory score was obtained based on the following formula (Tremonte et al. 2017)

Inhibition Score (IS) = Inhibition zone diameters $(\mathrm{mm}) /$ well diameter $(\mathrm{mm})$

The inhibitory effect of an antimicrobial compound considered to be low if $1<$ IS $<3$, moderate $3 \leq$ IS $<5$, strong $5 \leq$ IS $<7$, and very strong $7 \leq$ IS $<9$.

\section{Identification of the Antimicrobial-Producing Strain}

Cell from bacterial cultures were collected by centrifugation at $14.000 \mathrm{xg}$ for $1 \mathrm{~min}$. After discarding the supernatant, the total genomic DNA was extracted by using a Presto ${ }^{\mathrm{TM}}$ Mini gDNA Bacteria Kit (Geneaid, Taipei, Taiwan). The extracted DNA samples were amplified by polymerase chain reaction (PCR) using $16 \mathrm{~S}$ ribosomal RNA gene. PCR amplification used My Taq Red Mix (Bioline) and universal primers (27F: AGAGTTTGATCMTGGCTCAG and 1492R: TACGGYTACCTTGTTACGACTT) (Chao et al. 2008; Pringsulaka et al. 2012; Miao et al. 2014; Ahn et al. 2017). The DNA extract from isolates was mixed with PCR cocktail. The DNA templates used were $1 \mu \mathrm{L}$ for each reaction. PCR cocktail contain 12,5 $\mu \mathrm{L}$ MyTaq Red Mix $2 \mathrm{x}, 1 \mu \mathrm{L}$ both $27 \mathrm{~F}$ Primer and 1492R Primer with final concentrations $20 \mu \mathrm{mol} / \mu \mathrm{L}$, and ddH2O 9,5 $\mu \mathrm{L}$. The PCR condition contained pre-denaturation at $95^{\circ} \mathrm{C}$ for $1 \mathrm{~min}$, followed by 35 cycles consisting of $95^{\circ} \mathrm{C}$ for $15 \mathrm{sec}$, annealing at $52^{\circ} \mathrm{C}$ for $15 \mathrm{sec}$ and extension at $72^{\circ} \mathrm{C}$ for 45 sec, and final extension $72^{\circ} \mathrm{C}$ for $10 \mathrm{~min}$. PCR products were confirmed by gel electrophoresis on a $1.5 \%(\mathrm{w} / \mathrm{v})$ agarose gels, stained with ethidium bromide. The amplicons were purified by Zymoclean ${ }^{\mathrm{TM}}$ Gel DNA Recovery Kit (Zymo Research) according to the manufacturer's protocol and used as sequencing templates. The PCR products were sequenced by bi-directional sequencing at $1^{\text {st }}$ BASE (Singapore).

\section{Phylogenetic analysis}

The sequences of bacterial isolates were analyzed using Basic Local Alignment Search Tool (BLAST) at www.ncbi.nlm.nih.gov to the database of $16 \mathrm{~S}$ ribosomal RNA sequences (Bacteria and Archaea). The gene sequences were aligned with multiple alignments using Clustal W and Bioedit was used to remove the gap's region (Nguyen et al. 2014).

A phylogenetic analysis was performed by MEGA 7 to determine the closest bacterial species (Ahn et al. 2017). Model selection was determined using Find Best DNA/Protein Models (ML) in MEGA7. The selection was based on the lowest AICc (Akaike Information Criterion, corrected) score. The lowest AICc score was estimated to be the best model to be used in Maximum Likelihood analysis (Tamura et al. 2011).

\section{RESULTS AND DISCUSSION}

\section{Isolation of Lactic Acid Bacteria}

As much as twenty-nine isolates of LAB with clear zone on MRS agar with $\mathrm{CaCO}_{3}$ were isolated from chao. They were all screened on the basis of gram stain, catalase, motility and oxidase test. Six isolates (IB1C, IB3B, IB3C, IB3E, IB3F, IB6C) showed gram-positive properties, catalase negative, non-motile and endospore-negative (Table 1). 


\section{Detection of antimicrobial activity}

Antimicrobial activity was detected based on the ability of growth cells and CFS in inhibiting the growth of indicator strain. Among six LAB isolated from chao, four isolates showed an inhibition zone against $S$. aureus FNCC 0047 and E. coli FNCC 0049 (Table 2).

The detection of antimicrobial activity by growth cell assay against $S$. aureus FNCC 0047 showed that three isolates (IB1C, IB3B, IB3F) have moderate inhibition ability, while IB3E isolate produced a low inhibition zone. The cell cultures that produce large inhibitory zones indicates their potential to produce antimicrobial compounds. The inhibition zone diameters were in the range of 11.33 to $18.57 \mathrm{~mm}$. The widest inhibitory zone diameter was shown by IB1C isolate with $18.67 \pm 0.58$ $\mathrm{mm}$, while the narrowest inhibition zone were IB3C and IB6C isolates. They did not show any inhibition zone. The result showed that low activity or inactivation of IB3C and IB6C isolates do not mean that the two isolates are inactive or unable to produce antimicrobial compounds, but it can be due to the ability of an antimicrobial compound to diffuse in agar well medium. According to Valgas et al. (2007) diffusion process is influenced by several factors such as amount, size, and shape of diffuse substances. Hence, different bacterial strains have different activities so that the antimicrobial compounds produced by each isolate may also differ both in number, size, and shape. In addition, the size of the inhibitory zone depends on the speed of antimicrobial to diffuse with the media, and also depends on the growth rate of the indicator bacteria. The growth of isolate that tends to be slower than the indicator strains can cause the isolate has not enough time to form antimicrobial compounds in competition against the indicator strains on the test medium (Mariam et al. 2014).

Table 1. Characteristic of lactic acid bacteria from chao

\begin{tabular}{lccccc}
\hline $\begin{array}{c}\text { Isolated } \\
\text { no. }\end{array}$ & $\begin{array}{c}\text { Cell } \\
\text { shape }\end{array}$ & Gram & Catalase & Endospore & Motility \\
\hline IB1C & Rod & + & - & - & - \\
IB3B & Rod & + & - & - & - \\
IB3C & Cocci & + & - & - & - \\
IB3E & Cocci & + & - & - & - \\
IB3F & Cocci & + & - & - & - \\
IB6C & Cocci & + & - & - & - \\
\hline \multicolumn{2}{l}{ Note $:+=$ positive, $-=$ negative }
\end{tabular}

Table 2. Inhibition zone diameters of LAB isolated from Chao using $S$. aureus and E. coli as indicators

\begin{tabular}{|c|c|c|c|c|}
\hline \multirow{3}{*}{$\begin{array}{l}\text { Isolated } \\
\text { no. }\end{array}$} & \multirow{3}{*}{$\begin{array}{r}\text { Well } \\
(\mathbf{m m})\end{array}$} & \multicolumn{3}{|c|}{ Inhibition zone diameters (mm) } \\
\hline & & \multirow{2}{*}{$\begin{array}{c}\text { Growth cell } \\
\text { S. aureus } \\
\text { FNCC } 0047\end{array}$} & \multicolumn{2}{|c|}{ CFS } \\
\hline & & & $\begin{array}{c}\text { S. aureus } \\
\text { FNCC 0047 }\end{array}$ & $\begin{array}{c}\text { E. coli } \\
\text { FNCC 0049 }\end{array}$ \\
\hline IB1C & 5 & $18,67 \pm 0,58^{b}$ & $16,67 \pm 1,04^{b}$ & $14,67 \pm 1,15^{\mathrm{a}}$ \\
\hline IB3B & 5 & $15,67 \pm 1,15^{b}$ & $14,00 \pm 3,61^{\mathrm{a}}$ & $14,00 \pm 1,00^{\mathrm{a}}$ \\
\hline IB3C & 5 & - & - & - \\
\hline IB3E & 5 & $11,33 \pm 0,58^{\mathrm{a}}$ & $11,83 \pm 3,55^{\mathrm{a}}$ & $9,33 \pm 2,51^{\mathrm{a}}$ \\
\hline IB3F & 5 & $16,50 \pm 2,29^{b}$ & $13,60 \pm 1,80^{\mathrm{a}}$ & $9,33 \pm 0,57^{\mathrm{a}}$ \\
\hline IB6C & 5 & - & - & - \\
\hline
\end{tabular}

Note: Different letters in the same column means different IS, ${ }^{\mathrm{a}}=$ low, ${ }^{\mathrm{b}}=$ moderate
This study has also performed an assay that applied CFS to the isolates. The CFS was used in the test may provide an overview of the antimicrobial activity which is the extracellular metabolite compound produced by bacteria. Bacteriocin, one of the antimicrobial compounds is known to be an extracellular substance produced by bacteria (Mesa-Pereira et al. 2017). Antagonistic activity of CFS depends on extracellular bactericidal secretion. In the antimicrobial test of cell growth, the secretion process is controlled by the cell to cell interaction (Goers et al. 2014). However, in the CFS, the pure colony of isolates may have already secreted extracellular antimicrobial compound (Hettiarachchi et al. 2017). CFS produced by BAL contains organic acids, hydrogen peroxide, and diacetyl (Hor and Liong 2014).

The results of the CFS activity against $S$. aureus FNCC 0047 as a gram-positive bacteria showed that IB1C isolate has a moderate inhibition, while the other isolates (IB3B, IB3E, IB3F) have low inhibition. This difference occurs due to the amount of antimicrobial involved during the test process. On the testing of antimicrobial cell activity, we used $10^{7} \mathrm{CFU} / \mathrm{ml}$ cells for each isolate while the CFS test used a supernatant from isolate culture with a $1.5 \%$ initial concentration of inoculated isolates on MRS broth media with 24-hour incubation time. During the incubation process, growth cell and metabolites produced by each isolate can also be different because each strain of bacteria has different activities.

CFS inhibition activity depends on the active substance released to the supernatant. At low isolates, growth causes low antimicrobial activity (Mariam et al. 2014). The final concentration of metabolite products harvested from cultures can vary depending on strain, which causes the results of testing of the antimicrobial activity of IB1C CFS against CFS other isolates to be different (Abushelaibi et al. 2017). Interestingly, IB1C isolate, produced a low inhibitory activity against gram-negative $E$. coli FNCC 0049. The cell wall of $E$. coli is much more complex than cell walls of gram-positive bacteria. The outer membrane contains lipopolysaccharides (LPSs). The main function of LPSs is creating a permeability barrier that restricts the entry of antibiotic and other toxic substances that can kill or injure the bacterium (Willey et al. 2008). Moreover, based on antimicrobial from growth cell and CFS assay, IB1C isolate had the highest inhibition zone. The isolates with inhibition zone appeared were selected for further studies.

\section{Identification of the antimicrobial-producing strain}

Identification of four isolates that have antimicrobial activity was carried out by molecular characterization based on DNA sequence of $16 \mathrm{~S}$ rDNA. Two isolates (IB1C, IB3B) were identified as Lactobacillus plantarum with $100 \%$ similarities to accession number NR115605.1. Two isolates were identified as Pediococcus pentosaceus with 99\% similarity to accession number NR042058.1 (Table 3). According to Dighe et al., (2004) and Greenwood et al., (2012) if isolates have similarity of more than $97 \%$, they can be considered as the same species. Based on the evidence, the IB1C and IB3B isolates were 
considered as L. plantarum species, and IB3E and IB3F isolates were considered as $P$. pentosaceus. The similar studies about the isolation of lactic acid bacteria from fish fermentation products were reported that antimicrobial compound produced by $L$. plantarum and P. pentosaceus (Desniar et al. 2015; Budiarto et al. 2016; Wang et al. 2016).

Phylogenetic analysis can provide an estimation of the evolutionary relationship between microbial sequences. According to Madigan et al. (2010), 16S rRNA gene is widely used for the construction of phylogenetic trees because the sequence of nucleotide bases of rRNA molecules can precisely be compared, makes it easier to identify the diversity. The $16 \mathrm{~S}$ rRNA gene in bacteria has a high level of similarity because it is found in all prokaryotes. The $16 \mathrm{~S}$ rRNA gene also has variable and conserved regions, and it is this region reflects the phylogenetic relationship between species (Mitreva 2017).

The results of the $16 \mathrm{~S}$ rDNA sequence analysis showed that the IB3E and IB3F isolates clustered to the same branch as Pediococcus pentosaceus while the IB1C and IB3B isolates were clustered in the same group as Lactobacillus plantarum and Lactobacillus pentosus. Several studies on the isolation of the LA from fish fermentation products also showed similar results. Wang et al. (2016) in their study succeeded in isolating $L$. plantarum 120 from fish fermentation product from China, Suanyu. L. plantarum JCM-1149 produce antimicrobial compounds that inhibit the growth of Listeria monocytogenes (Nursyam et al. 2016). Kusmarwati et al. (2014) also reported the isolation of $P$. pentosaceus I from the Bangka and Kalimantan regions as a producer of antimicrobial compounds as bacteriocin. Thus, it can be concluded that the lactic acid bacteria found in fermented fish product are strains of L. plantarum and P. pentosaceus.
According to our investigations, this is the first publication about isolation on antimicrobial producing L. plantarum and $P$. pentosaceus from chao.

In conclusion, Four LABs isolated from chao could produce antimicrobial against both of both gram-positive and negative bacteria. The highest antimicrobial activity was observed in IB1C isolate. Based on molecular identification, IB1C and IB3B isolates were identified as $L$. plantarum, whereas IB3E and IB3F isolate identified as $P$. pentosaceus. Therefore further research should be followed to use these isolates as an inoculum in controlling of contamination of food product as a natural preservative.



Figure 1. The results of DNA amplification with $27 \mathrm{~F}$ and $1429 \mathrm{R}$ primers. (M: Marker $1 \mathrm{~Kb}$ DNA Ladder (Geneaid), 1: IB3B, 2: IB3E, 3: IB3F and 4: IB1C)

Table 3. BLAST result of the isolate from chao

\begin{tabular}{|c|c|c|c|c|}
\hline Isolate & Species of LAB homolog & Identities & $\begin{array}{c}\text { Accession } \\
\text { number }\end{array}$ & Isolate sources \\
\hline \multirow[t]{5}{*}{ IB1C } & Lactobacillus plantarum strain JCM 1149 & $100 \%$ & NR_115605.1 & Pickled cabbage \\
\hline & Lactobacillus plantarum strain NBRC 15891 & $99 \%$ & NR_113338.1 & Pickled cabbage \\
\hline & Lactobacillus plantarum strain CIP 103151 & $99 \%$ & NR_104573.1 & Frozen peas \\
\hline & Lactobacillus plantarum strain NRRL B-14768 & $99 \%$ & NR_042394.1 & Jojoba meal fermentation \\
\hline & Lactobacillus pentosus strain $124-2$ & $99 \%$ & NR_029133.1 & Corn silage \\
\hline \multirow[t]{5}{*}{ IB3B } & Lactobacillus plantarum strain JCM 1149 & $100 \%$ & NR_115605.1 & Pickled cabbage \\
\hline & Lactobacillus plantarum strain NBRC 15891 & $99 \%$ & NR_113338.1 & Pickled cabbage \\
\hline & Lactobacillus plantarum strain CIP 103151 & $99 \%$ & NR_104573.1 & Frozen peas \\
\hline & Lactobacillus plantarum strain NRRL B-14768 & $99 \%$ & NR_042394.1 & Jojoba meal fermentation \\
\hline & Lactobacillus pentosus strain $124-2$ & $99 \%$ & NR_029133.1 & Corn silage \\
\hline \multirow[t]{4}{*}{ IB3E } & Pediococcus pentosaceus strain DSM 20336 & $99 \%$ & NR_042058.1 & Dried American beer yeast \\
\hline & Pediococcus stilesii strain FAIR-E 180 & $98 \%$ & NR_042401.1 & White maize grain \\
\hline & Pediococcus acidilactici strain DSM 20284 & $98 \%$ & NR_042057.1 & Barley \\
\hline & Pediococcus claussenii strain ATCC BAA-344 & $98 \%$ & NR_075029.1 & Fermented Beverage spoiled beer \\
\hline \multirow[t]{4}{*}{ IB3F } & Pediococcus pentosaceus strain DSM 20336 & $99 \%$ & NR_042058.1 & Dried American beer yeast \\
\hline & Pediococcus stilesii strain FAIR-E 180 & $98 \%$ & NR_042401.1 & White maize grain \\
\hline & Pediococcus acidilactici strain DSM 20284 & $98 \%$ & NR_042057.1 & Barley \\
\hline & Pediococcus claussenii strain ATCC BAA-344 & $98 \%$ & NR_075029.1 & Fermented Beverage spoiled beer \\
\hline
\end{tabular}




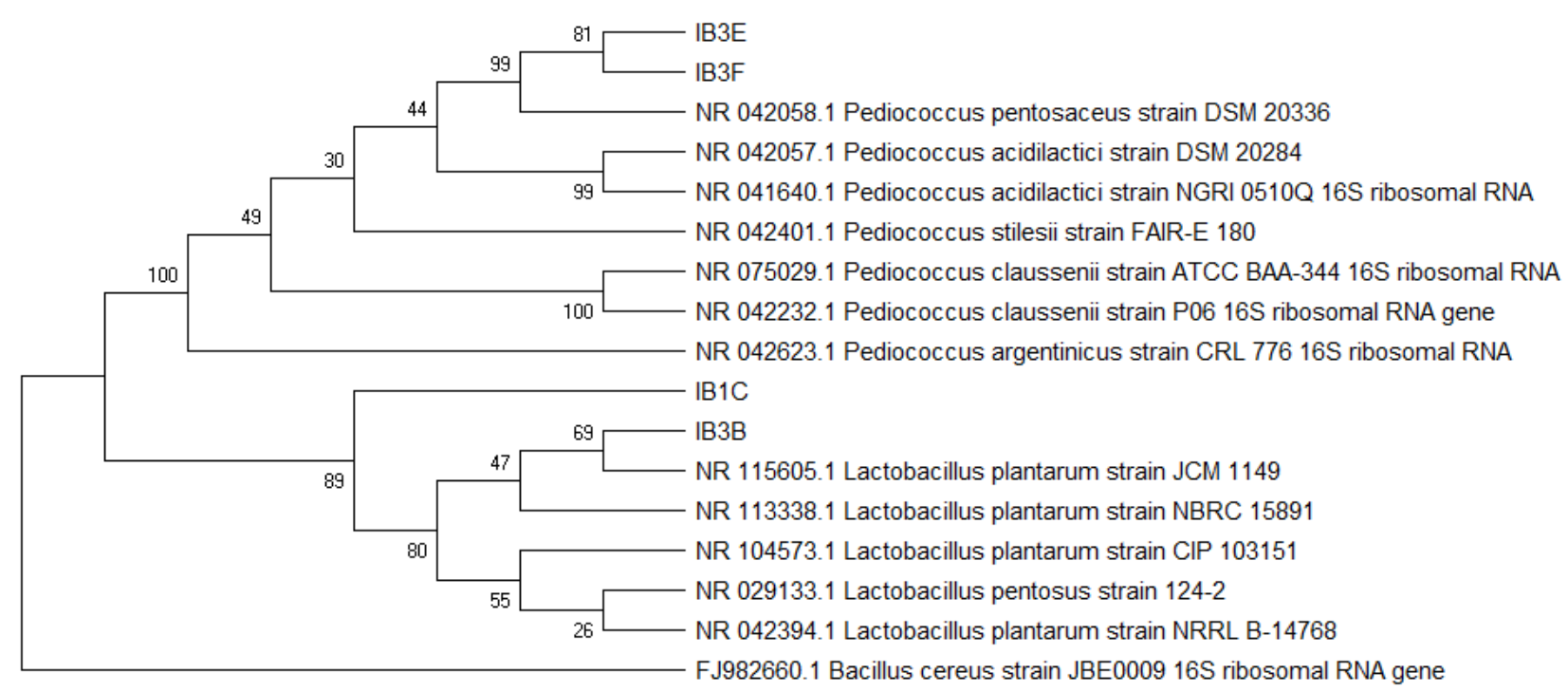

Figure 2. Phylogenetic tree isolates of lactic acid bacteria from chao using Maximum Likelihood (bootstrap = 1000)

\section{ACKNOWLEDGEMENTS}

This research was supported by Unggulan Scholarship. We also would like to thank the technician in FALITMA Laboratory, Faculty of Biology, Universitas Gadjah Mada, Yogyakarta, Indonesia for her helpful authorization to use laboratory equipment.

\section{REFERENCES}

Abushelaibi A, Al-Mahadin S, El-Tarabily K, Shah NP, Ayyash M. 2017. Characterization of Potential Probiotic Lactic Acid Bacteria Isolated from Camel Milk. LWT-Food Sci Technol 79: 316-325.

Adams MR, Moss MO. 2008. Food Microbiology. 3rd ed. The Royal Society of Chemistry, UK.

Agussalim M. 2017. Characteristics of tembang fish (Sardinella gibbosa) as a raw material for Chao fermentation products. Jurnal Galung Tropika 6: 72-80. [Indonesian].

Ahn H, Kim J, Kim WJ. 2017. Isolation and Characterization of Bacteriocin-producing Pediococcus acidilactici HW01 from Malt and Its Potential to Control Beer Spoilage Lactic Acid Bacteria. Food Contr 80: 59-66.

Assohoun-Djeni NMC, Djeni NT, Messaoudi S, Lhomme E, KoussemonCamaraa M, Ouassa T, Chobert JM, Onno B, Dousset X. 2016 Biodiversity, dynamics and antimicrobial activity of lactic acid bacteria involved in the fermentation of maize flour for doklu production in Côte d'Ivoire. Food Contr 62: 397-404.

Axelsson L. 2004. Lactic Acid Bacteria: Classification and Physiology. In Salminen S, Wright AV, Ouwehand A (eds). Lactic Acid Bacteria: Microbiological and Functional Aspects. $3^{\text {rd }}$ ed. Marcel Dekker Inc., New York.

Budiarto, BR, Mustopa, AZ, Idarmawan T. 2016. Characterization of partially extracellular proteases from bekasam-isolated Lactobacillus plantarum S31 and its application to hydrolyze skimmed-milk with antibacterial property. Intl Food Res J 23: 340-349.

Chao S, Tomii Y, Watanabe K, Tsai Y. 2008. Diversity of lactic acid bacteria in fermented brines used to make stinky tofu. Intl J Food Microbiol 123: 134-141.

Desniar, I. Rusmana, A. Suwanto, Mubarik DNR. 2015. Characterization of lactic acid bacteria isolated from an Indonesian fermented fish (bekasam) and their antimicrobial activity against pathogenic bacteria. Emir J Food Agric 25 : 489-494.

Dighe AS, Jangid K, Gonzalez JM, Pidiyar VJ, Patole MS, Ranade DR, Shouche YS. 2004. Comparison of 16S rRNA gene Sequences of Genus Methanobrevibacter. BMC Microbiol 4: 1-12.

Goers L, Freemont P, Polizzi K. 2014. Co-culture system and technologies: taking synthetic biology to the next level. JR Soc Interface 11: 20140065 .

Greenwood D, Barer M, Slack R, Irving W. 2012. Medical Microbiology A Guide to Microbial Infections: Pathogenesis, Immunity, Laboratory Investigation and Control. 18th ed. Churchill Livingstone-Elsevier Ltd., New York.

Hettiarachchi SA, Lee SJ, Lee Y, Kwon YK, Zoysa MD, Moon S, Jo E, Kim T, Kang DH, Heo SJ, Oh C. 2017. A rapid and efficient screening method for antibacterial compound-producing bacteria. J Microbiol Biotechnol 27: 1441-1448.

Hor YY, Liong MT. 2014. Use of Extracellular Extracts of Lactic Acid Bacteria and Bifidobacteria for Inhibition of Dermatological Pathogen Staphylococcus aureus. Dermatol Sin 32: 141-147.

Indriati N, Setiawan IPD, Yulneriwarni. 2006. Potential of antimicrobialproducing lactic acid bacteria from peda, jambal roti, and bekasam. Jurnal Perikanan 8: 153-159. [Indonesian]

Karim M, Susilowati A, Saokani J. 2013. Identification of diversification result and development of various processed fish product specific to Makassar. Jurnal Balik Diwa 4: 19-28. [Indonesian]

Koesoemawardani D, Hidayati S, Subeki S. 2018. Amino acid and fatty acid compositions of Rusip from fermented Anchovy fish (Stolephorus sp). IOP Conf Ser: Mater Sci Eng 344: 012005. DOI: 10.1088/1757-899X/344/1/012005

Kusmarwati A, Arief FR, Haryati S. 2014. Exploration of Bacteriocin from lactic acid bacteria origin from Bangkanese and Kalimantanese rusip. JPB Perikanan 9: 29-40. [Indonesian]

Lakong J. 2003. Processing technique of skipjack tuna chao with the addition of tape during fermentation in South Sulawesi. Hasanuddin University, Makassar.. [Indonesian]

Madigan MT, Clark DP, Stahl D, Martinko JM. 2010. Brock Biology of Microorganism $13^{\text {th }}$ eds. Benjamin Cumming. San Fransisco.

Mariam HS, Zegeye N, Tariku T, Andargie E, Endalafer N, Assefa A. 2014. Potential of Cell-Free Supernatants from Culture of Selected Lactic Acid Bacteria and Yeast Obtained from Local Fermented Foods as Inhibitors of Listeria monocyte genes, Salmonella spp., and Staphylococcus aureus. BMC Res Notes 7: 606.

Mesa-Pereira B, O'Connor PM, Rea MC, Cotter PD, Hill C, Ross RP. 2017. Controlled Functional Expression of The Bacteriocins Pediocin PA-1 and Bactofecin A in Escherichia coli. Sci Rep 7: 3069. 
Miao J, Guo H, Ou Y, Guo L, Fang X, Liao Z, Ke C, Chen Y, Zhao L, Cao Y.. 2014. Purification and Characterization of Bacteriocin F1, a Novel Bacteriocin Produced by Lactobacillus paracasei subsp. tolerant FX-6 from Tibetan Kefir, a Traditional Fermented Milk from Tibet, China. Food Contr 42: 48-53.

Mitreva M. 2017. The Microbiome in Infectious Diseases. In Cohen J, Powderly WG, Opal SM (eds) Infection Diseases (Fourth Edition). Elsevier 68-74. www.sciencedirect.com.

Nguyen VD, Pham TT, Nguyen THT, and Nguyen TXN. 2014. Screening of Marine Bacteria with Bacteriocin-like activities and Probiotic Potential for Ornate Spiny Lobster (Panulirus ornatus). Fish Shellfish Immun. 49-60.

Nursyam H 2016. Antibacterial Activity of Pediococcus acidilactici 0110<-tat-1, Lactobacillus plantarum JCM-1149 and Lactobacillus casei NRRL-B1922 Against Listeria monocytogenes ATCC-1194. Asian Jr Microbiol Biotech Env Sci 19: 43-48.

Pringsulaka O, Thongngam N, Suwannasai N, Atthakor W, Pothivejkul K, Rangsiruji A. 2012. Partial characterization of bacteriocins produced by lactic acid bacteria isolated from Thai fermented meat and fish product. Food Contr 23: 547-551.

Ray B. 2005. Fundamental Food Microbiology. 3rd ed. CRC Press, New York.

Sanches, PC. 2008. Philiphine Fermented Food: Principle and Technology. The University of The Philippine Press. Quezon City, Philippines.
Sirichokchatchawan W, Pupa P, Praechansri P, Am-in N, Tanasupawat S, Sonthayanon P, Prapasarakul N. 2018. Autochthonous lactic acid bacteria isolated from pig faeces in Thailand show probiotic properties and antibacterial activity against enteric pathogenic bacteria. Microb Pathog 119: 208-215

Tremonte P, Pannella G, Succi M, Tripaldi L, Sturchio M., Coppola R, Luongo D, Sorrentino E. 2017. Antimicrobial Activity of Lactobacillus plantarum Strains Isolated from Different Environment: A Preliminary Study. Intl Food Res J 24: 852-859.

Tamura K, Peterson D, Peterson N, Stecher G, Nei M, Kumar S. 2011. MEGA5: Molecular Evolutionary Genetics Analysis Using Maximum Likelihood, Evolutionary Distance, and Maximum Parsimony Methods. Mol Biol Evol 10: 2731-2739.

USFDA. 2015. Microorganisms and microbial-derived ingredients used in food (Partial List). U.S. Food and Drug Administration, Washington, DC. https: //www.fda.gov.

Valgas C, Souza SM, Smania EFA, Smania JrA. 2007. Screening methods to determine the antibacterial activity of natural products. Braz $\mathrm{J}$ Microbiol 38: 369-380

Wang W., Xia W, Gao P, Xu Y. 2016. Sarcoplasmic Protein Hydrolysis Activity of Lactobacillus plantarum 120 Isolated from Suanyu: A Traditional Chinese Low Salt Fermented Fish. J Food Process Preserv 41: 2 .

Willey J, Sherwood LM, Woolverton CJ. 2008. Prescott, Harley, and Klein's Microbiology. 7th ed. McGraw-Hill Companies Inc., New York. 